This item was submitted to Loughborough's Research Repository by the author.

Items in Figshare are protected by copyright, with all rights reserved, unless otherwise indicated.

\title{
Perpetrators of the Holocaust: a historiography
}

PLEASE CITE THE PUBLISHED VERSION

http://www.palgrave.com/products/title.aspx?pid=687350

\section{PUBLISHER}

(c) Palgrave Macmillan

\section{VERSION}

AM (Accepted Manuscript)

\section{LICENCE}

CC BY-NC-ND 4.0

\section{REPOSITORY RECORD}

Szejnmann, Claus-Christian W.. 2019. "Perpetrators of the Holocaust: A Historiography". figshare. https://hdl.handle.net/2134/13336. 
This item was submitted to Loughborough's Institutional Repository (https://dspace.lboro.ac.uk/) by the author and is made available under the following Creative Commons Licence conditions.

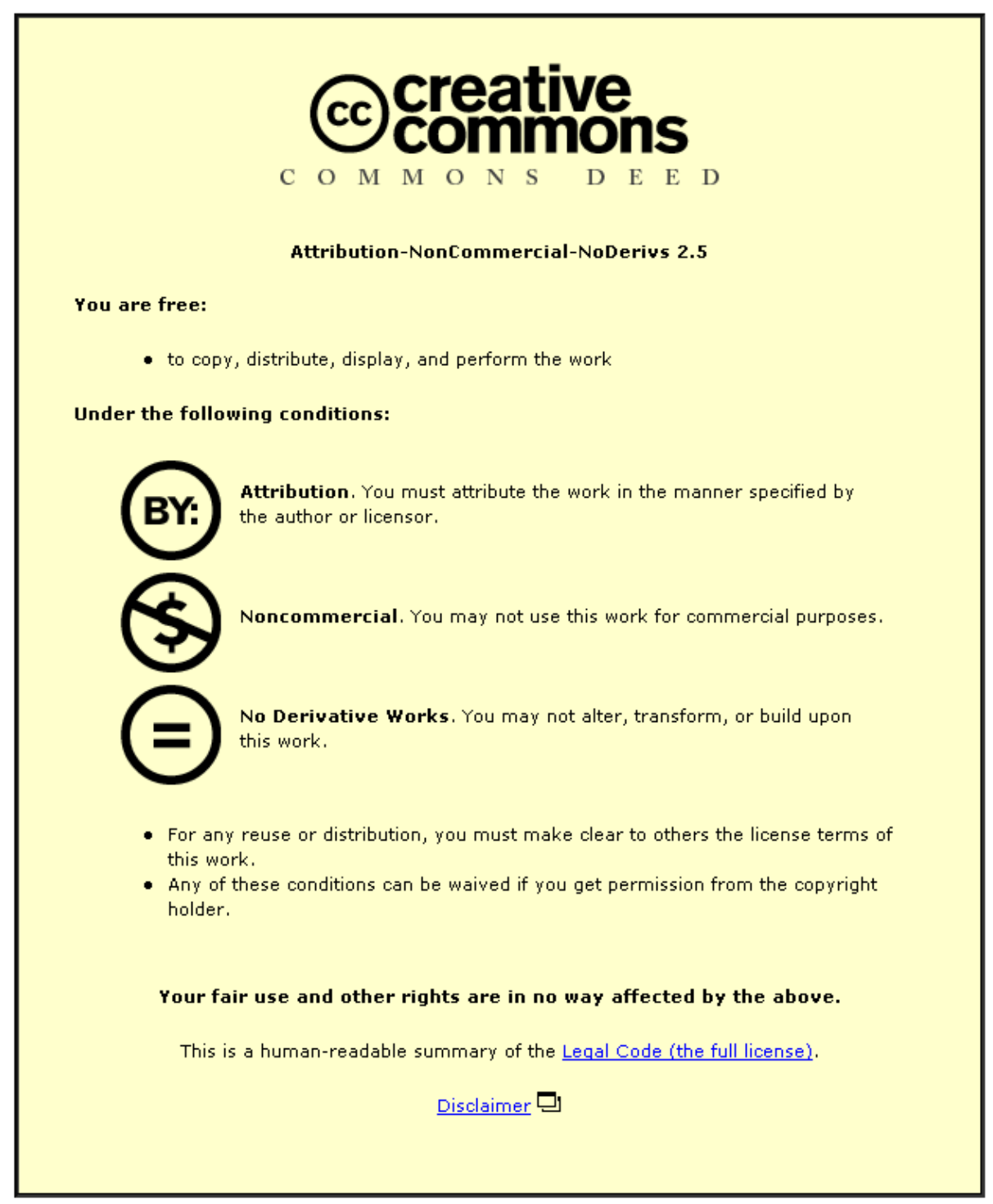

For the full text of this licence, please go to: http://creativecommons.org/licenses/by-nc-nd/2.5/ 


\section{Perpetrators of the Holocaust: A Historiography}

Claus-Christian W. Szejnmann

\section{Confronting the Holocaust: questioning humanity and facing insurmountable challenges}

In late 1944 and early 1945 the British Foreign Office gave British soldiers a pocket guide to prepare them to conquer Germany and occupy it afterwards. The guide argued that Hitler had exploited Germany’s tradition of authority and glorification of war, and had moulded a new generation of brutal killers. The Germans, the guide concluded, differed sharply from the British people: 'The likeness, if it exists at all, is only skin-deep. THE DEEPER YOU DIG INTO THE GERMAN CHARACTER, THE MORE YOU REALISE HOW DIFFERENT THEY ARE FROM US. ${ }^{1}$

In the end, however, nobody seemed prepared for the horrors discovered by Allied soldiers. The depth and extent of what humans had suffered under the Nazi dictatorship questioned the core of humanity and posed serious challenges. Whilst it seemed imperative to tell what happened, to learn from it, to punish the perpetrators, and to explain why it happened, it emerged quickly that this was far from an easy task. It seemed obvious that the barbaric crimes called for a new departure in identifying and punishing those responsible. The Allied powers agreed that 'German militarism and Nazism will be wiped out' (Potsdam, August 1945) and publicly called for retribution for the crimes - at the time it was estimated that there were hundreds of thousands of perpetrators - set up military tribunals, and targeted 'German officers and men and members of the Nazi Party who have been responsible for or have taken a consenting part' in atrocities, war crimes and crimes against humanity. ${ }^{2}$ However, in 
the western occupied zones the coming of the Cold War led to a dramatic transformation from a punitive approach to focusing on reconstructing a capitalist economic system with the help of the old elites. Whilst in the Soviet zone deNazification is often regarded as more successful - it was quicker and more rigorous the Communists used the situation to carry out a general purge against everyone who opposed them, made compromises with former Nazis to stabilise the dictatorial rule, and pretended that the restructuring of their society had 'liberated' East Germany from Nazi oppression.

Finally, explanations about the relationship between Germans, Nazism and acts against humanity varied and proved to be far from straightforward. Whilst the British troops were taught that Germans had been shaped by sinister traditions and an evil dictator, direct contact with Germans suggested a more complex picture. Three years after the end of the Second World War the US psychologist H. L. Ansbacher published a study based on surveys of German POWs. When trying to explain why Germans had supported Nazism, and why, even after its defeat and after the 'discovery’ of its horrific nature, half of the German population continued to believe that 'National Socialism was a good idea only badly carried out', Ansbacher concluded:

What did the respondents mean by the 'idea' of National Socialism and the way in which it was carried out? Did they mean the idea of the master race, compulsions, aggression, and did they mean that this idea was not carried out with sufficient consistency? If this were the case, the German mind would indeed be a most perplexing problem and cause for alarm. Our results lead us to the strong belief that when half the Germans today assert the idea of National 
Socialism was good, but badly carried out, they mean primarily the idea of social and economic betterments, and find fault with its realization through oppression, aggression, and persecution. In this event the problem of the German mind is much less puzzling. No change of basic motives and goals is needed, only a more complete understanding on the part of the Germans of the real meaning of National Socialism, namely, that its vicious aspects were inseparably intertwined with its more constructive sides. ${ }^{3}$

The discourse about perpetrators of the Holocaust until the 1980s: suppression and denial in perpetrator societies and societies with collaborators - the stigma of pathological killers - the paradigm of a 'mechanised' crime The Nazi racial Dictatorship was the most genocidal regime the world has ever seen. It is often forgotten that around 3 million Poles, 7 million Soviet civilians, and 3.3 million Soviet POWs were murdered because they were regarded Slavic 'subhumans'. The sociology of its perpetrators, who killed approximately 20 million unarmed people, occupies a central place in the study of the Holocaust and has a contemporary meaning. ${ }^{4}$ How many people took part in the mass murder? What kind of people were they? What were their reasons for their murderous activities? And what were the consequences of their deeds? Some of these perpetrators still live with us or are known to us as family friends or acquaintances, fathers or mothers, uncles or aunts, grandfathers or grandmothers. These questions also deal with the uncertainty whether the mass murder of the Jews was a singular historic event, or, because potentially it may be rooted in the nature of humans, it can be repeated.

There have been sharply contrasting interpretations whether and how these issues have been addressed in Germany. ${ }^{5}$ Did German society suppress the past and 
conserve deep-rooted anti-democratic tendencies underneath the surface?

Alternatively, did it readily engage with the Nazi past and transform into a vibrant democracy? Or, do these issues require differentiated answers that reflect failures, shortcomings as well as success? Thomas Kühne is in no doubt that the Nazi past was always present in the public life of Germany. However, he is also quick to point out that one has to distinguish carefully what aspects of the Nazi period and its aftermath were discussed, in what manner, with what objectives and to what effect within both German states, during the various periods of their history and by what groups, classes, generations, professions, confessions, and political camps, and by which gender.

In countries that were dominated by Nazi Germany the discourse about the war focused on a small number of well-known agents of Nazi rule, the trauma suffered under Nazi occupation (Austria complained of having been the first victim of Nazi aggression), resistance (France, Poland), partisan warfare (Yugoslavia), or the 'great war of the fatherland' (Soviet Union) - all of which served as tools to integrate and legitimise their respective post-war societies. The painful and divisive issue of widespread collaboration, a crucial component of how the occupiers were able to establish their rule, and the role of local agents in the persecution of the Jews and other minorities, was swept under the carpet and received little attention. ${ }^{6}$ Additionally, research on the Holocaust in the Eastern Bloc was strongly ideologized before it became more or less insignificant. ${ }^{7}$

Considering the continuity in personnel in more or less all sectors of West German society after the defeat of the ‘Third Reich’ and the fact that many Germans had been perpetrators, accomplices or bystanders, it cannot be a surprise that most Germans were not keen on dealing with the topic of perpetrators, and kept secret or minimized the crimes of the past. ${ }^{8}$ More than anything else, the Nuremberg Trials of 
War Crimes shaped the way in which perpetrators were dealt with and the discourses on perpetrators and memory in West Germany in the post-war period. Following the debates concerning the responsibilities for the crimes, only the Gestapo and the SS were classified as ‘criminal organisations' whilst regular police, plainclothes police and the Wehrmacht successfully escaped the mantra of guilt: whilst Himmler's black corps was demonized, it isolated the crime institutionally and allowed large parts of the population to exonerate themselves from any guilt (according to Gerald Reitlinger, the SS became the 'alibi of a nation' ${ }^{9}$ ). Even Eugen Kogon, a Holocaust survivor and one who was highly critical of the way how most Germans denied any guilt, in his influential book The SS-State (the German edition had been published in 1947) described Hitler and his SS-henchmen as failed characters who suffered from inferiority complexes and were in 'naked pursuit of power':

What we are dealing with here are not baffling mysteries of human nature, but violations of simple, basic, psychological laws in the evolution of inferior minds. It was inferiority - whether of minds, reason, willpower, imagination or the numerous social aspects of the human mind - that led these men into the SS. $^{10}$

Other important developments also shaped collective perceptions and the specific discourse on perpetrators. Otto Ohlendorf, the leader of Einsatzgruppe D, claimed during the Einsatzgruppen trial in Nuremberg that the murder of Jews was based on a clear order from Hitler (i.e., that there was a central plan for the Final Solution) and therefore amounted to following 'Führer orders': 
BABEL [defence lawyer]: But did you have no scruples in regard to the execution of these orders?

OHLENDORF: Yes, of course.

BABEL: And how is it that they were carried out regardless of these scruples? OHLENDORF: Because to me it is inconceivable that a subordinate leader should not carry out orders given by the leaders of the state ...

HERR BABEL: Could any individual expect to succeed in evading the execution of these orders?

OHLENDORF: No, the result would have been a court martial with a corresponding sentence. $^{11}$

This line of argument reduced perpetrators to mere executioners of an alien will steered by Hitler, Himmler and Heydrich (who were all dead but were treated as principal offenders) and emphasised that any resistance would have had deadly consequences. This defence strategy quickly became commonplace and helped many accused to go unpunished especially after 1949 when German courts judged the overwhelming majority of killers as 'assisting' in murders which they as individuals apparently did not want. ${ }^{12}$ This interpretation turned the bearers of terror into victims of terror - i.e. ordinary Germans were prisoners of a specific historical period and structures and were condemned to obedience. ${ }^{13}$

The representation of female perpetrators and their defence strategy in various Nazi trials is a largely neglected topic but played an important part of the collective strategy of denying any guilt. ${ }^{14}$ Accused women exploited their gender status by arguing that they had been exploited and had acted in subordinate positions as helpless assistants in a regime that was led by men. Furthermore, analyses of 
‘courtroom-culture’ and media representation of trials show that female perpetrators were stereotyped and demonized as complete deviations from femininity and exceptional ‘female brutes’, e.g., Ilse Koch, ‘the witch from Buchenwald’, Carmen Maria Mory, 'the devil’ of Ravensbrück, or Herta Oberheuser, 'the sadist [doctor; CCWS] of Ravensbrück'. This discourse disguised the participation of a large number of women in Nazi crimes, and served to avoid a critical self-reflection of the past. In short, the picture of 'unnatural femininity' and dehumanised creatures with unbridled sexuality allowed society to construct a counter-model of itself as normal and innocent.

In the late 1940s and early 1950s there was no complete repression or denying of responsibilities for the crimes committed in the name of the German people in Germany. However, Germans practised what Robert Moeller described as 'selective memories’. In Germany the discourse focused not on the horrors the Jews had suffered under the Nazis, but on German victimization and Soviet barbarism, i.e. crimes committed against German expellees and POWs. ${ }^{15}$ Futhermore, according to Ulrich Herbert, public perception

made connections with images of the liberation of the concentration camps Bergen-Belsen, Buchenwald, or Dachau - and not with the mass shootings in Riga or the mass gassings in Auschwitz. In this way, the process of mass murder was construed as a series of secret events that occurred in specially cordoned-off zones in 'the east' to which no witnesses were granted access. ${ }^{16}$

Perpetrator historiography uncritically followed the interpretation that blame and responsibility for the Holocaust lay with a few top Nazi leaders, in particular Hitler. 
The Führer was portrayed as a crazy, irrational and opportunistic demagogue, who ordered the final solution. ${ }^{17}$ It took decades until some historians engaged more analytically with Hitler only to discover that he had a 'cohesive world view'. ${ }^{18}$ The focus, however, remained on questions of order and timing - Was there a Führer order to the 'Final Solution'? Did Hitler decide on the mass murder of the Jews in the 1920s? When exactly was the decision made to kill all Jews? - all of which are important issues but ultimately do not address key humanitarian and moral questions raised by the Holocaust. The spotlight on Hitler simplified the dynamics and complexities of Nazism, and the notion of an 'evil monster' diverted attention from the responsibilities of others.

A number of high-profile court-cases from the late 1950s 'broke the general silence about the perpetrators' and ignited debates about the mass crimes committed under Nazism, most importantly: the Einsatzgruppen trial in Ulm in 1958, the Eichmann trial in Jerusalem in 1961, and the Auschwitz trial in Frankfurt in the mid1960s. A new generation of historians, whose well-known publication Anatomie des SS-Staates was expert evidence prepared for and in part delivered at the trial of war criminals in Frankfurt and was published by the Institute for Contemporary History in Munich, provided solid 'analyses of the motives, structure, and methods of the leaders of the National Socialist regime'. ${ }^{19}$

Overall, however, Holocaust research at West German universities remained a marginal topic until the late 1980s. Instead, historians were preoccupied with searching for the background to why the Nazis came to power, and the turn to structural history in West German historiography meant that debates centred on system theory. This was an era when the concept of 'totalitarianism' blossomed (vilifying the socialist dictatorships as equivalent to National Socialism during the 
Cold War), and when historians were locked into a bitter stalemate between 'intentionalists’ and ‘structuralists'. Peter Longerich recently highlighted the narrowmindedness of a debate in which apparent contrasts were, in fact, mutually conditional and reflected multi-layered and complex phenomena that cannot be grasped with onedimensional explanations: humans who want to carry out mass murder depend on structures, whilst structures do not function on their own but need humans; regional initiatives were an integral part of centrally controlled policies; pragmatic explanations for the persecution of Jews were backed up by ideological justifications and vice versa. $^{20}$

As it stood, influential books by Karl Dietrich Bracher focused on the intellectual origins and the organisational development of the Nazi dictatorship, and perpetrators did not feature in prominent anthologies about the Nazi dictatorship or the massive 'Bavaria Project' of the Institute for Contemporary History. ${ }^{21}$ Notable exceptions in the 1970s were two studies that went largely unnoticed: Uwe Dietrich Adam investigated the coordination of various national institutions in the persecution of the Jews and was the first German historian who questioned the linear development that ended in genocide, and Christian Streit highlighted the central role of the Wehrmacht in the death of some $57 \%$ of Soviet POWs. ${ }^{22}$ Although the knowledge of the killing process was at best rudimentary, German scholarship largely ignored international developments in the field, ${ }^{23}$ and the huge amount of rich material that had been generated by prosecutors in criminal proceedings against Nazi criminals. After all, the historical professions had played a crucial role in legitimising German claims to the East, the Nazi programme of ethnic cleansing and the genocide against European Jews. When, after 1945, the same historians and then their protégés continued to hold chairs at German universities, it made sense for them to pretend to 
be 'emotionally detached and "neutral” in [their] approach. ${ }^{24}$ It was indicative that a rare study based on court material by the criminologist Herbert Jäger in the late 1960s was largely ignored by historians although it was highly innovative on several accounts. ${ }^{25}$ It demolished the perpetrators' principal line of defence that they had acted under binding orders: Jäger could not find a single case in which someone who did not obey criminal orders was physically harmed. The book also emphasised the link between the war and genocide, and presented an important contribution about the individual motivation of Nazi perpetrators, a topic that other psychologists and criminologists had previously tackled but with little conviction. Jäger suggested a new typology that distinguished between excess crimes (crimes committed on one's own initiative and in disinhibitory conditions), crimes committed in a relative autonomous way, and crimes committed by following orders. Furthermore, some Holocaust survivors and critical authors responded to the horrors that were exposed by the court cases, the mild sentencing of mass murderers and the repression of the Nazi past: autobiographical accounts by Jean Améry and Primo Levi, or theatre plays by Rolf Hochhuth ('The Deputy') and Peter Weiss ('The Investigation') reached a mass audience. ${ }^{26}$

Meanwhile, highly influential non-German books on the Holocaust - e.g., works by Lucy Dawidowicz and Nora Levin that were largely based on secondary sources and put forward simplistic explanations which Raul Hilberg described bitterly as examples of 'manipulation in history' 27 - perpetuated the notion of evil leaders and popular irrational anti-Semitism. ${ }^{28}$ There were, however, also scholars who produced outstanding and original scholarship that improved our understanding of the systematic mass murder of the Jews. The works of two scholars stood out. The philosopher Hannah Arendt was a leading voice amongst German-Austrian Jews and 
Holocaust survivors. In The Origins of Totalitarianism (1951) she attempted to explain why the relatively unimportant phenomena of the Jewish question and antiSemitism became the catalytic agent leading to the rise and success of Nazism, a world war and finally the crime of genocide. ${ }^{29}$ Her explanation suggested the emergence of the new form of totalitarian rule that was built upon irrational terror and ideological fiction. To Arendt, totalitarian regimes were capable of mobilising populations where a viable public life with conditions of liberty and freedom had been uprooted by devastating developments in the modern period (industrialisation, population movements, modern warfare, revolutionary upheaval, etc.). According to Arendt, 'absolute evil' emerged in totalitarian societies - 'absolute because it can no longer be deduced from humanly comprehensible motives’. In the process, antiSemitism and other motivating factors disappeared behind the 'inherent logicality’ of mass murder. Terror became an end in itself to 'stabilise' men and formed the essence of totalitarian domination. ${ }^{30}$

Arendt's thesis that the annihilation of the Jews followed some kind of inner logic broadened the scope of perpetrators to encompass all of German society, and influenced generations of historians. Hilberg's seminal work The Destruction of the European Jews from 1961 exploited a massive body of empirical evidence and interpreted the Shoah as a process of successive steps that were initiated by countless decision-makers inside a vast bureaucratic apparatus that was operating and coordinating on an unprecedented scale. ${ }^{31}$ This bureaucratic machinery was driven by a shared comprehension, synchronisation and efficiency, and was not limited by any morals because the process was dehumanised (e.g., the Commandant of Treblinka and Sobibor, Franz Stangel, described the Jews as 'cargo'). According to Christopher Browning, Hilberg's great contribution was to portray an extensive 'machinery of 
destruction' that 'was structurally no different from organized German society as a whole.' Indeed, 'the machinery of destruction was the organized community in one of its specialized roles.' Moreover, these bureaucrats 'were not merely passive recipients of orders from above' but ‘innovators and problem solvers'. ${ }^{32}$ However, Hilberg's overall focus on the bureaucratic process and the structure of extermination, emphasising the division of labour in the killing process, meant that there was still no detailed focus on the background and motivation of perpetrators. In other words, whilst Hilberg had put the perpetrator at the centre of his analysis and emphasised the involvement of a large number of groups in the killing process, his focus was on the role of perpetrators as members of an institution rather than as individuals. ${ }^{33}$

The 1961 trial of Adolf Eichmann boosted discussions on the Holocaust. ${ }^{34}$ The trial is often associated with Hannah Arendt's famous book Eichmann in Jerusalem: A Report on the Banality of Evil. Arendt was clearly influenced by Hilberg's study and depicted the Shoah as a modern, bureaucratically-organised and industriallydriven extermination process in which Eichmann was merely a mechanical link. Her description of Eichmann's actions as 'banal' was meant to challenge the prevalent notion that the mass murder was carried out by a limited number of pathological killers and outsiders. To Arendt, Eichmann appeared very ordinary, but, like most other Germans, 'had succumbed to Hitler' and was therefore afflicted by an 'inability to think'. With this, 'the moral maxims which determine social behaviour and the religious commandments - “Though shalt not kill!” - which guide conscience had virtually vanished'. Eichmann was not determined by 'fanaticism' or violent antiSemitism, but by his ‘extraordinary loyalty to Hitler and the Führer’s order’. ${ }^{35}$

Gerhard Paul argued that this paradigm of the 'mechanized' crime has been the central explanation for the Shoah until today. ${ }^{36}$ Martin Broszat, who in 1958 
published the autobiographical notes of Rudolf Höß, commandant of Auschwitz, described an executioner who appeared to be a normal petit-bourgeois human who zealously and unemotionally obeyed orders from authorities and was part of a factorylike and anonymous mass murder. This new picture of perpetrators entailed that they were not particularly evil, but orderly, conscientious, and thus appeared extremely suitable to take part in the anonymous mechanism of modern mass murder. A flood of publications described Eichmann's mediocre normality and depicted him as model example of the loyal bureaucrat - a cog in a machine that operated beyond his control - hence the description 'banal bureaucrat' and 'bureaucratic murderer'. Authors from Israel in particular criticised Arendt's assessment that in the modern world all humans are potential Eichmann's and are not aware of the consequences of their actions. To some, this minimises the horrific crimes that were committed and gives them a universal character. To others, like Raul Hilberg, 'there was no "banality” in this "evil”” as Eichmann was not only a loyal bureaucrat but rather a trailblazer for continuously finding new ways in achieving the incredible dimension of his barbaric deed. Finally, Alf Lüdtke warned that by describing automatic processes without humans one re-affirms a widespread consensus amongst the perpetrator society that denied that each killing had to be carried out again and again by the will and action of the perpetrators. ${ }^{37}$ Not surprisingly, Ulrich Herbert described this period as 'the second suppression of the past' in Germany. ${ }^{38}$ Gerhard Paul argued that the Shoah turned into an 'automatism without people' that 'found its description in the metaphor of the "factory of death"': Auschwitz. This discourse did not deal with the activities of killers in shooting pits or the liquidations of ghettos, and enabled 'normal' Germans once more to distance themselves from the perpetrators. ${ }^{39}$ 
There was, to be true, a widespread trend to conceptualise the Holocaust. Marxist scholars in the GDR continued to describe fascism as the most imperialist element of finance capital. Theodor Adorno argued that the support for fascism, antidemocracy and anti-Semitism in the inter-war period was caused by the appearance of an 'authoritarian personality'. And the Jewish sociologist Zygmunt Bauman in his book Modernity and the Holocaust proposed 'to treat the Holocaust as a rare, yet significant and reliable, test of the hidden possibilities of modern society’. ${ }^{40}$

However, change was on the way and approaches and methodologies diversified especially in German historiography in the course of the 1980s (there is no room here to discuss the growing attention amongst the American public to the Holocaust from the mid-1970s ${ }^{41}$ ). Several factors help to explain this. The airing of the fictional television series Holocaust in 1979 had a significant impact in West Germany and, according to Judith Doneson, broke 'a thirty-five-year taboo on discussing Nazi atrocities’, whilst Federal President Richard von Weizäcker’s groundbreaking speech on 8 May 1985, which 'placed Jews, Poles and Russians higher up the list of victims than the German themselves', indicated change at the highest political level. ${ }^{42}$ The turn towards local history and the history of everyday life meant that coming to terms with one's past took place in real terms, including a growing awareness of the places of crimes and the perspective of victims - albeit the aspect of perpetrators continued to be neglected for a long time. ${ }^{43}$ Furthermore, increasing research on the 'Third Reich' heightened the awareness about the enormous gaps in the knowledge about the Holocaust - and German scholarship re-joined an international debate on the topic. Moreover, critics who have attacked 'functionalists' in particular for depersonalizing the Holocaust, have often not recognised that historians such as Hans Mommsen and Martin Broszat drew attention away from the Nazi leadership 'towards different 
functional elites in the bureaucracy, military and judiciary, their interaction and, ultimately, towards German society at large. ${ }^{44}$ Hence, the racial activities of institutes and social groups beyond the SS attracted some attention. The policies against the Jews appeared more and more as the core of a comprehensive policy of extermination that unleashed its destructive features during the war and that involved the participation of all key institutions of the ‘Third Reich’ and targeted a growing number of victims: Hans-Heinrich Wilhelm presented a detailed description of the murderous activities of Einsatzgruppen in Belarus and the Baltic nations in the context of early occupation policies; Ernst Klee, a social worker for the handicapped, produced a major study of the Nazi ‘euthanasia’ killing (in which around 250,000 people were murdered); the geneticist Benno Müller-Hill revealed the involvement of German geneticists and anthropologists in the selection of Jews, Gypsies, the mentally ill and the retarded, for sterilization and genocide; Gisela Bock published an important study about forced sterilization (between 320,000 and 350,000 people were sterilised in accordance with Nazi racial criteria); Hans-Walter Schmuhl explored the concept of racial hygiene and the euthanasia killing; Ulrich Herbert looked at the war economy, the exploitation of foreign slave workers (around 7.7 million foreign men and women were forced to work in Nazi Germany by autumn 1944), and the role of employers; and Burkhard Jellonek studied the treatment of homosexuals. ${ }^{45}$ Many new impulses came from ‘outside’ the mainstream German scholarship, including nonhistorians, who turned to empirical studies of everyday life and mentalities, published sources about the actual killing process, and discovered the importance of letters from the front. ${ }^{46}$

These original studies on organisational, ideological, regional and biographical aspects of Nazism led to a much better understanding of the Nazis’ policies of 
extermination and the role and motivation of perpetrators. For instance, Michael Zimmermann demonstrated that the Nazi policy of persecution against the Romani 'drew on traditional anti-Gypsy prejudices, but managed to radicalize them at decisive points by representing them as scientifically sound with the aid of social and biological theories.' There was 'no evidence of a unified process of decision-making ... nor of a corresponding chain of command for the murder of "Gypsies"' (more than 200,000 Gypsies were killed in the Holocaust). ${ }^{47}$ Meanwhile, researchers abroad were also producing innovative studies. ${ }^{48}$ One notable pioneer was the US-Israeli historian Omer Bartov with his investigation of the unprecedented brutalities committed by the German Wehrmacht in the East. Bartov challenged the post-1945 memories of loyal and self-sacrificing German soldiers who were victims first of the Nazi regime, then of partisan terror, and then of Stalin's military aggression and captivity. He explained the murderous activities of soldiers, from top ranking officers to foot soldiers, with a combination of 'the terrible physical and mental hardship at the front', the draconian military system of repression and, most crucial, ‘ideological conviction’ and ‘a general and widespread support [for], if not "belief”, in Hitler' ${ }^{49}$

\section{'Perpetrator studies' since the 1990s: locating 'ordinary' men and women as mass murderers - confronting motives and actions of killers - acknowledging victims}

The 1990s proved to be the decade when mainstream scholarship and the public in Germany were ready to confront the National Socialist past head-on for the first time and debate it as never before. Bill Niven argued that 'the time was right' not only because of special anniversaries (e.g., the $50^{\text {th }}$ anniversaries of Stauffenberg's attempt on Hitler's life and the end of the war) and spectacular media events (e.g., Steven 
Spielberg's film Schindler's List in 1993), but, more importantly, because German unification brought an awareness and acceptance of a common past. Furthermore, the crucial impact of generational shifts, particularly in the 1960s and again the 1980s, explained why 'the 1990s where a continuation and radicalization of a process of coming to terms with the past, rather than its first phase. ${ }^{50}$ Scholarship and the wider public realm were now ready to confront what stood at the heart of the Nazi dictatorship and the Holocaust: war, genocide, perpetrators and crime scenes, the precise implication of every group in society in mass murder, and, of course, the victims. One could argue that the opening of the massive Memorial to the Murdered Jews of Europe in the centre of Berlin in 2005 has finally shifted the fate of the victims of Nazism right into the heart of German society.

A real break-through in scholarship was Christopher Browning's exemplary micro-analysis from 1992 of around 500 members of Police Battalion 101, a unit comprising middle-aged reservists from a working-class or petit-bourgeois background in Hamburg. ${ }^{51}$ Most of the men were not fanatical Nazis, but took part in the Holocaust in Poland and shot at least 38,000 Jews. Browning's focus on the murderous activities and motivation of these 'ordinary men' - the great majority of them became executioners although they had the possibility of not participating in these mass shootings - put this key issue at the top of the scholarly agenda for the first time. The US scholar based his research on court proceedings from the 1960s and, favouring a multi-causal, anthropological approach, argued that the behaviour of these men was determined by a combination of factors: a willingness to obey orders and authority, group conformity and peer pressure, career-mindedness, the brutalising effects of a racist imperialist war, and the insidious effects of constant propaganda and indoctrination. Anti-Semitism, according to Browning, played only a minor role. 
Browning's complex conclusion was influenced by the Milgram and Stanford prison experiments and emphasised how social group processes create specific conditions which can have a de-inhibiting effect, potentially turning ‘ordinary men’ into brutal murderers. ${ }^{52}$ To Browning, the genocide against the Jews was a unique consequence of the potential for destruction in the modern age. He also emphasised that the Shoah should not be seen as the execution of a central decision to exterminate but as a process in which local initiatives played a crucial role (pioneering work about the Holocaust in the occupied territories - e.g. in the Lublin district, Belarus and Galicia have meanwhile confirmed this ${ }^{53}$ ). Furthermore, with reference to Primo Levi he asked scholars to pay more attention to complex and contradictory aspects of human behaviour, i.e. the 'Gray Zone’ of victims (e.g., the corruption and collaboration that flourished in the camps) and perpetrators (e.g., 'the pathetic figure' of commander Trapp, 'who sent his men to slaughter Jews "weeping like a child””). ${ }^{54}$

The controversy surrounding the 'Crimes of the Wehrmacht' exhibition and the 'Goldhagen debate’ sparked off a massive public discussion about perpetrators. Suddenly the spotlight was on locating killers and their motives at the heart of society, and the brutal suffering of victims. The public was confronted with the accusation that ‘ordinary’ Germans participated in systematic mass murder (previously, similar findings had not received much public reaction). The breaking of the 'visual taboo' regarding the Shoah made this situation even more dramatic. Whilst Goldhagen described the barbaric killings in graphic detail and used photos as source - e.g. how an 'ordinary' German soldier 'takes aim at a Jewish mother and child during the slaughter of the Jews of Ivangorod, Ukraine, in 1942' - the exhibition displayed photos, letters and documents of 'ordinary' soldiers taking part in the widespread mass-murder of civilians and Soviet POWs. ${ }^{55}$ Suddenly perpetrators and bystanders 
of the crimes were not anonymous any more but identifiable individuals, sometimes neighbours, relatives or even one's own father. The 'Wehrmacht' exhibition in particular sparked off an unprecedented public response because it challenged a collective memory and 'one of the founding myths of the German Federal Republic the legend of a "decent” army that had steered clear of atrocities perpetrated by the SS. ${ }^{56}$

Whilst the Wehrmacht exhibition was largely concerned with setting the record straight, Goldhagen's aim was to explain the motivation of ‘ordinary’ killers. Like Browning, he dismissed the thesis that perpetrators were exceptional pathological killers and that the Shoah was an abstract industrial Genocide. Instead, both emphasised that it was a mass murder carried out by a large number of individual perpetrators. In particular, Goldhagen stressed that each individual is an autonomous being and responsible for his/her actions, and also possesses freedom to make decisions about whether or not to participate in actions that violate human morals. ${ }^{57}$ But whilst Goldhagen analysed the same sources as Browning (witness statements in the court case against members of Police Battalion 101), he came to strikingly different conclusions: he saw the Shoah rooted in Germany's specific political and cultural development and argued that 'ordinary’ Germans became 'Hitler’s willing executioners' because of a deep-seated 'eliminationist anti-Semitism'.

At a time when empirical research suggested the complex multi-causal nature of the Holocaust, Goldhagen was turning the clock back to simplistic interpretations. However, the debate that was sparked off by Goldhagen’s probing questions and provocative theses exposed serious deficiencies in our knowledge about key aspects of the Holocaust, and led to the acceptance that a change of paradigm, already started by Browning, was essential. This included shifting the focus from the Nazi elite to 
‘ordinary Germans’ as killers; a cultural anthropological approach that incorporates a detailed analysis of the crimes and responsibilities of individual perpetrators; and an attempt to situate the crimes in the context of the wider society. Furthermore, it became clear how little was known about the precise extent, form and role of antiSemitism and its link with the Holocaust, and how this virulent German anti-Semitism compared to other forms of this phenomenon. ${ }^{58}$

One final contributor who deserves singling out for making a whole range of original and challenging contributions to the then newly-emerging subject of Perpetrator Studies (Täterforschung) was the Berlin historian Götz Aly. Aly, in tandem with Susanne Heim, argued in the early 1990s that there was a 'political economy of the Final Solution' - i.e. young planners identified overpopulation as the source of a deep-rooted structural problem of the region and aimed to spark off a revival and modernisation of the economy by destroying the socio-economic existence of Polish Jews. ${ }^{59}$ Whilst this thesis did not convince many fellow experts it is difficult to prove the impact of these ideas on policy, and one striking feature of the Holocaust seemed to be precisely the irrelevance of economic criteria - Aly and Heim challenged mainstream scholarship: they proved that those responsible for the extermination policy were not restricted to the SS and the Nazi party, and they insisted that the Holocaust was not motivated by irrational racial hatred but primarily ‘utilitarian goals’. Aly, Heim and a whole group of like-minded scholars who published books on the role played by young, well-trained experts such as statisticians, economists, doctors and historians, saw Nazism as providing them with a unique opportunity to realise their shared visions of a rationalised social and economic utopia. 
In the mid-1990s Aly’s book Final Solution provided empirical basis for the amended thesis that the policies against the Jews became radicalised due to the failure of plans for the deportation of the Jews. ${ }^{60}$ However, as Herbert points out, whilst Nazi deportation plans ‘also involved Poles, Russians, even entire populations of countries lying to Germany's east', their failure only led to the practice of genocide against the Jews. This raised fundamental questions:

What role then did anti-Semitism play here? In what way did the dilemmas real or contrived - arising in specific situations link up with long-standing attitudes and aims? What was the relationship between ideological factors, such as racism and hatred of Jews, to goal-oriented, 'rational' motives, such as economic modernization or dealing with food scarcity? How did the motives both individual and situationally determined - of the murderers and those who bore responsibility for their actions relate to a general dynamic of violence directed against Jews? ${ }^{61}$

After Browning, Goldhagen and Aly had thrown down the gauntlet to their peers, perpetrator studies became a 'boom’ subject amongst a new generation of historians who exploited the newly available documents in the former Eastern Block states. The new interest in people and protagonists led to a turn towards the history of mentalities (Mentalitätsgeschichte) and biographical studies, an emphasis on detailed empirical research, a focus on comparative typologies and motivations of perpetrators, and the exploration of the decentralised perspective of the policies of extermination in the occupied territories. $^{62}$ 
The core group of perpetrators near the top of the Nazi hierarchy, the men who bore responsibility for the organization of the mass murders, emerged as an ‘ideological elite’. For instance, the leadership of the Reich Security Head Office (RSHA; maybe the most central group of planner-perpetrators) were born after the turn of the century in the middle and upper strata of German society, were radicalised by war and post-war crisis, and were influenced by völkisch racism, enthusiasm for technology and ideas of a 'heroic realism' (term referring to murderous actions not being based on hatred but on rationality, i.e. killing did not spark off empathy as it served the interest of the Volk). ${ }^{63}$ These educated members of the core group of perpetrators, like the key official in Heydrich’s security police apparatus, Werner Best, or Götz Aly’s ‘ethnic planners’, camp commandants, Gestapo chiefs, Einsatzgruppen commanders, Sipo and SD, SS and police leaders, 'Jewish experts', and T-4 killers, were technically efficient and well-trained professionals. But whilst each group had their own 'generational, social, and/or professional homogeneity', they were all willing and committed ideologues who exploited their considerable autonomy to pursue their vision of a racist world order ('ideological bureaucracy'). ${ }^{64}$ This ideal was worth any sacrifice and transcended any traditional limits. Ideological commitment, although it was complex and varied, played a crucial dual function amongst the core group of perpetrators: it served as motivation for individuals and provided a focus of orientation for a variety of competing interests. This helps to explain the smoothly functioning division of labour and the 'networks of Nazi persecution’ that coordinated genocide in a polycratic environment. ${ }^{65}$

The more recent research has increasingly focused on the 'shooters' - the rankand-file Einsatzkommandos, Reserve Police, Waffen-SS, and Wehrmacht - who were composed mainly of a cross-section of German-Austrian society. Members of these 
vast groups had no typology: 'no age, gender, social, educational, ethnic, or religious cohort proved immune to involvement' ${ }^{66}$ But whilst individuals had different biographical patterns and showed individual forms of behaviours, like members of Einsatzgruppe D who carried out mass killings in the south of the Soviet Union, their murderous impact was frighteningly homogenous. ${ }^{67}$ Two interpretations about the dramatic transformation from upright burgher to brutal killer seem worth mentioning. Klaus-Michael Mallmann dismisses the common explanation such as obedience to orders, the brutalisation of war and the impact of propaganda because these murderous shooters had volunteered and there was no time to get used to violence and to be affected by propaganda. Instead, he argues that the radicalisation of the anxiety and hatred of 'Jewish Bolshevism', a sentiment that had gradually grown since 1917, became virtual reality when confronted with ‘alien’ Jews in enemy territory and legitimised 'the removal of a collective security risk as necessary self-defence. ${ }^{\text {, }} 8$ Whilst there is a growing body of research on perpetrators from the Wehrmacht, Thomas Kühne has recently provided the first comprehensive explanation of what turned 'ordinary' soldiers into murderers, why these soldiers fought so long in a war that was lost, and what explains the way how soldiers communicated their experiences after $1945 .^{69}$ At the heart of his explanation stands the concept of comradeship which was central to everyday social practices of the military community and its moral rules - and which entailed enormous pressures to conform. It included the shared experience of being away from home, being accomplice in murder and then belonging to the 'community of suffering' when the war turned against Germany. Soldierly comradeship was the epitome of everything 'good'. Kühne concludes: 'The "human” side of comradeship made the 'inhumane' side of 
war bearable, morally as well as emotionally', but it simultaneously functioned as the motor of violence as peer pressure made an opt-out extremely difficult.

The growing interest in women and the Holocaust and in the social environment of perpetrators led to the scholarly 'discovery' of the female perpetrators - until then an almost completely neglected topic. The ‘feminist' Historikerstreit (struggle amongst historians) over whether women were victims of an extreme male-dominated and sexist-racist Nazi dictatorship that reduced women to the status of mere 'objects' (Gisela Bock), or whether women played an active role in the regime and shared some responsibilities for the crimes (Claudia Koonz) constructed an over-simplistic perpetrator-versus-victim dichotomy. ${ }^{70}$ It is only more recently that studies about the personnel of perpetrator groups, in particular research about the 'euthanasia' killing and concentration camps, made visible the important and varied functions women fulfilled as perpetrators and bystanders in mass murder. ${ }^{71}$ Female doctors, nurses, midwifes and administrative assistants directly or indirectly participated in the killing of innocent people in the Nazi 'euthanasia' programme. ${ }^{72}$ Women worked as cooks, office personnel, nurses, laboratory assistants, doctors, and camp guards in women's divisions in some of the best-known concentration camps, such as AuschwitzBirkenau, Majdanek, Bergen-Belsen, Mauthausen, Dachau, and Sachsenhausen, and in numerous women concentration camps, such as Ravensbrück, Moringen and Lichenberg. In total, around 10 percent of all camp guards, i.e. 3,500, were female. They participated in tormenting and torturing prisoners, and helped to select and murder victims. Female perpetrators pursued their work under no duress, regarded concentration camps as a normal place of work and the attached SS estate as a normal place to live in, and often perceived inmates as 'sub-humans' who had no right to live in the Nazi state. Gudrun Schwarz argued that SS-wives (240,000 women were 
married to SS men) were directly involved in the system of terror by providing domestic and emotional stability at the place of crime for the husbands, and by actively participating in the system of exploitation and robbing. Some wives of members of the SS or the Gestapo even volunteered to take part in encroachments and shootings. ${ }^{73}$ Overall, female perpetrators worked as efficiently and professionally as their male counterparts to ensure a smooth killing process. They were not passive tools in the apparatus of repression but used their freedom to pursue personal initiatives.

Very recently an expert stated bluntly that 'the full history of wartime collaboration in much of eastern Europe remains to be written. ${ }^{74}$ However, scholarship has made considerable progress since the discourse about societies in Nazi-occupied territories hardly went beyond the description of stigmatized collaboration and heroic resistance. A discussion about the motives of non-German perpetrators exemplifies the complexities of the subject. Michael MacQueen argued that there were six basic motivations for, or types of, Lithuanian perpetrators:

1. Revenge, by those who had suffered at the hands of the Soviets.

2. Careerists, who sought personal advancement under the new regime.

3. Turncoats, who attempted to expiate service to the Soviets by enthusiastic loyalty to their new masters.

4. Greedy individuals, seeking to gain booty.

5. Anti-Semites, who had baited the Jews before the war and participated in antiJewish violence under the Nazis.

6. So-called accidental perpetrators, who just happened to be recruited and went with the flow. ${ }^{75}$ 
Martin Dean, who studied the motivations of police volunteers in the killing in Belarus and the Ukraine, came independently to almost identical conclusions. He argued, however, that one could add the 'sadistic types' and 'those who lusted for power'. Dean also believed that 'usually a combination of several of these motivations played a role within each individual'. Furthermore, whilst anti-Semitism played an important motivation amongst some local policemen who participated in the killing, 'it was more a matter of personal animosity for political or economic reasons' and lacked the dehumanizing racial basis of Nazi ideology. MacQueen and Dean also stress the 'gruesome intimacy of the killings'. Many of the perpetrators 'personally knew the victims and had lived together with them previously as schoolmates, co-workers, and neighbours.' Hence local economic and personal relations played an important role. Dean concluded: 'The active core was driven particularly by self-made careerists, the dynamic force of any society, who were particularly susceptible to the new opportunities and the disorientation of society's moral compass created by Nazi rule.’

Finally, sociologists, psychologists, anthropologists, political scientists and others, have shown sustained interest in topics dealing with violence, killing, mass murders, ethnic cleansing and genocide over the last two decades or so. ${ }^{76}$ Their 'multifaceted approaches and different “models” of explanation' have stimulated and broadened the discourse on perpetrator studies of the Holocaust. Two main approaches have stood out amongst scholars who have tried to answer what motivates mass murder and genocide. Whilst one group insists that murderous events like genocide 'have occurred throughout history in all parts of the world', another group emphasises 'change over continuity’, and, for instance, links modernity with genocide 
(those pursuing comparative genocide studies approach the Holocaust not as a 'unique' event but as an extreme form of genocide). Some social psychologists have offered particularly innovative analyses. James Waller has developed a complex theory that looks at the interaction among dispositional, situational and social factors. ${ }^{77}$ He emphasises the importance of moral disengagement, a gradual process in which perpetrators distance themselves from the victims and become capable of producing extraordinary evil. This ‘culture of cruelty’ rewards individuals for violence against victims and is stimulated by professional socialisation, binding factors of the group, and the merger of role and person. Harald Welzer, in a study that bears great similarities to Waller's findings, investigated the social psychological parameters, i.e. the moral concepts of the majority group in society, combined with a micro-study of the crime and the killing. ${ }^{78}$ He argued that most humans have the potential to turn into mass murderers. This happens through a process in which the majority group’s feeling of solidarity towards a minority has vanished and systematic killing is not regarded as a crime but is desired.

\section{Conclusions and future perspectives}

Our knowledge and understanding of the Holocaust, the instruments of terror and their personnel, have made enormous progress over the last decade. ${ }^{79}$ Perpetrator Studies has established itself as new discipline within the broad topic of National Socialism and has contributed towards many innovative findings. ${ }^{80}$ These studies aim to analyse the interaction between the structures of persecution, the bureaucracy of extermination, the (group) biography of perpetrators below the top Nazi leadership, the motivation of mass murderers beyond madness and racial hatred, the act of killing, and the time and place of killing. There were probably several hundred thousand 
Germans and Austrians who planned, organised, carried out and assisted persecution and murder. They were complemented by thousands of ethnic Germans (Volksdeutsche) who often pursued auxiliary functions, and hundreds of thousands of foreign auxiliaries. ${ }^{81}$ The forms of persecution and murder, and the motivation behind them, were extremely broad. Typical, however, was the mixture of state-prescribed and individually initiated violence - forms of violence which were difficult to separate and mutually conditional - through which they received their particular power and dynamics. The latest research suggests that there were at least three periods of political socialisation that shaped a 'radicalising career': the violent völkisch-Nazi milieu in post-war Weimar (climate of hate, racist prejudice and glorification of violence), the integration into Nazi organisations and an internalisation of violence during the Nazi dictatorship after 1933 (turning 'pre-war extremists' into 'full-time Nazis'), and the terrorist milieu in the occupied territories after 1939 (cumulative radicalisation and violence with a de-inhibiting effect; socialisation in violent comradeship). Overall, research suggests that whilst disposition is more important among the 'architects' of genocide, the behaviour of the 'shooters' is more determined by situational factors. It is likely that the largest group of perpetrators only radicalised after 1939 into ‘wartime Nazis’. However, the social psychologist Leonard Newman reminds us of the enormous complexities involved at any level: Personal and situational factors

interact in complicated ways ... Situations do not only interact with dispositional factors to affect behaviour, they also shape and change those dispositions: people do not just react to situations ... and finally, 'situations' themselves do not even objectively exist but need to be cognitively constructed 
by the people they then go on to affect ... While attitudes do indeed give rise to behavior, it is also the case that one's behavior affects one's attitudes and beliefs ... The cognitive dissonance literature shows that when people are led to engage in behaviors that violate their normal standards, they will be motivated to change their attitudes and beliefs to reduce the discrepancy between their behaviour and their cognitions. ${ }^{82}$

These and many other insights represent great achievements in Perpetrator Studies but cannot obscure the fact that the list of shortcomings, desiderata, and methodological problems remains daunting. ${ }^{83}$ The importance of racist ideology, and in particular anti-Semitism, in the mass murder has reoccupied centre stage but remains disputed. The core group of men who organised genocide were willing and committed ideologues. Furthermore, Christopher Browning now believes that the 'significant minority’ of so-called 'eager-killers' amongst low-level perpetrators were ideologically motivated to kill Jews and not overtly influenced by 'situational/organization/institutional factors'. ${ }^{84}$ However, among the majority of killers it is impossible to establish a direct causal relation between fanatical antiSemitism and actually killing Jews. Even the most committed racist ideologues, including Wildt's 'generation of the unbound', required a process of 'cumulative radicalization' 'to the point where they could actually comprehend that the most extreme conclusions of their ideas were realizable. ${ }^{85}$ Also, how exactly did moral scruples and human ethics disintegrate: was it, for example, a mixture of escalating pragmatism and social-Darwinist racism during a radicalising war? Or, did years of political and social indoctrination by the Nazis create a 'new moral conscience' that discarded universal human rights? ${ }^{86}$ Why did the mentality in the occupied territories 
(endemic corruption and violent excess, particularly in the East) differ so much from that of the old Reich (bureaucratic inhumanity and measures of persecution). ${ }^{87}$ Furthermore, George Browder raises a number of crucial questions that remain unanswered:

Were those who behave proactively at all levels 'normal' representatives of German society or a radicalized minority? Were all involved 'normal' representatives of Western industrial societies, individuals whom extraordinary circumstances and pressures had turned into perpetrators? ... What made the difference for those who withdrew or even resisted? ${ }^{88}$

And finally: how do humans live with murderous crimes? And how do perpetrators re-integrate themselves into society?

There are also serious limitations and methodological problems. Whilst many experts see the most promising approach in biographical analyses (following Herbert's study of Best), the biographical source base is often very limited (particularly for members of the lower classes), long-term personal dispositions often appear of only limited importance for the situational behaviour of a person, and perpetrators often acted collectively, in an environment of bureaucracy or comradeship, where their individual character disappeared. More generally, shortages of primary sources and inherent problems with existing sources put severe limits to our abilities to analyse the motivation of killers: e.g., the most prominent perpetrator analyses are based on witness statements and testaments from court trials (Browning, Goldhagen); most accounts on collaborators are based on oral testimonies from war crimes investigations; female camp guards hardly left any letters, diaries, personal 
notes or even post-war interrogations. Most perpetrator studies are based on predominantly German (Nazi) sources and do not take into consideration the perspectives of the victims of genocide and occupation. ${ }^{89}$ Furthermore, Jürgen Matthäus has warned that whilst more and more researchers have studied (and at times have become obsessed with) the personalities of perpetrators, their crimes and the crime locations, 'the more we restrict our analysis to the incriminating act, the greater the risk of severing casual and chronological connections with other, no less relevant aspects of the past' ${ }^{90}$ Finally, the call by some historians for multi-causal interpretations based on multi-disciplinary approaches has only been partially attempted. However, social psychological explanations which concentrate on group dynamics (but are often ahistorical - i.e., they neglect specific historical conditions and cultural factors, including ideology - and have a tendency to down-play the responsibility of perpetrators) can provide essential additions to historical attempts to find answers to why normal people became mass murderers under Nazism. ${ }^{91}$

Other serious challenges remain. There are still hardly any attempts for a systematic gender perspective in Perpetrator Studies, and it is necessary to reflect anew about the methodologies of how to write women's history under Nazism. It is not clear to what extent or whether at all the systematic investigations of their male counterparts are applicable to women. Susannah Heschel argues: ‘there is a widely shared assumption that men's cruelty is, in part, an expression of masculinity, but no exploration into whether women's acts of cruelty are linked to expressions of their femininity, understanding both terms as social constructs. ${ }^{, 92}$ There are also difficult pedagogical tasks. In Germany, the gap between historical knowledge and the willingness to confront the past in ones’ own immediate environment has not changed since Anna Rosmus became the 'nasty girl' of Passau for exploring Nazism in her 
home town in the early 1980s. In fact, there is a widespread acceptance throughout Western European societies today that Nazism was evil and collaboration was often as deadly, but, according to private family discourses, there were never any Nazis or Nazi sympathisers in ones’ own family. On the contrary, according to family memories the whole of Europe was full of heroic resistance fighters. ${ }^{93}$ The enormous reaction to the controversial book Neighbours. The Destruction of the Jewish Community in Jedwabne (Poland) from 2000/1 by the sociologist Jan Tomasz Gross exemplifies how difficult and sensitive the discussion of local collaboration in the Holocaust continues to be more than 60 years after the defeat of Nazism. ${ }^{94}$ More generally, knowledge of the mass murder during the Nazi dictatorship has become so complex and multilayered that it is hardly of any pedagogical use.

Finally, several leading experts have called for a more holistic approach in Holocaust studies. This questions the predominant historiographical focus on the perpetrators and promises to give Perpetrator Studies an innovative momentum. ${ }^{95}$ Peter Longerich expressed the need for a more comprehensive and understandable explanation of the events, for integrating perpetrator studies into the whole period between 1933 and 1945. He argues that the structuring of the debates in the form of the now classic dichotomies (was the decision to murder rooted in 'predisposition' or ‘situation’? Were perpetrators driven by ‘utilitarian’ or ‘ideological’ motives? Was the murder driven locally or by the centre?) does not do justice to the complexities of the topic. Similarly, Saul Friedlander demands an 'integrated history of the Holocaust' that includes German activities; activities from authorities, institutes and various groups in societies in the occupied countries and satellite states; Jewish perceptions and reactions; and simultaneous description of events on all levels and at 
various places. This promises to enhance the perception of the scale, the complexity and mutual interweaving of the enormous number of components of the Holocaust.

${ }^{1}$ Germany 1944. The British Soldier's Pocketbook (reprint, Kew, 2006), 26 (capital letters as in original).

2 Jürgen Matthäus, 'Historiography and the Perpetrators of the Holocaust', in Dan Stone (ed.), The Historiography of the Holocaust (Houndmills, 2004), 197-215, here, 197.

${ }^{3}$ H. L. Ansbacher, 'Attitudes of German Prisoners of War: A Study of the Dynamics of National-Socialist Followership’, Psychological Monographs. General and Applied, 62 (1) 1948, 38f.

${ }^{4}$ For this see Thomas Kühne, 'Der nationalsozialistische Vernichtungskrieg und die "ganz normalen” Deutschen. Forschungsprobleme und Forschungstendenzen der Gesellschaftsgeschichte des Zweiten Weltkrieges. Erster Teil’, Archiv für Sozialgeschichte, 39 (1999), 580-662, here 589.

${ }^{5}$ For this see Thomas Kühne, 'Der nationalsozialistische Vernichtungskrieg im kulturellen Kontinuum des Zwanzigsten Jahrhunderts. Forschungsprobleme und Forschungstendenzen der Gesellschaftsgeschichte des Zweiten Weltkrieges. Zweiter Teil’, Archiv für Sozialgeschichte, 40 (2000), 440-486, here 475f.

${ }^{6}$ Klaus-Michael Mallmann and Gerhard Paul, 'Die Gestapo. Weltanschauungsexekutive mit gesellschaftlichem Rückhalt’, in Klaus-Michael Mallmann and Gerhard Paul (eds.), Die Gestapo im Zweiten Weltkrieg "Heimatfront" und besetztes Europa (Darmstadt, 2000), 599650, esp. 633-637; Martin Dean, 'Where Did All the Collaborators Go?’, Slavic Review, 64 (4) (2005), 791-798.

${ }^{7}$ Dieter Pohl, however, emphasises the important Polish work by Artur Eisenbach (Hitlerowska polityka zagłady Żydów, Warsaw, 1961) that explained the origins of the persecution of the Jews in racial biology. See Dieter Pohl, 'Die Holocaust-Forschung und Goldhagens Thesen’, Vierteljahreshefte für Zeitgeschichte, 45 (1997), 1-48, here 2. 
${ }^{8}$ For the following see Gerhard Paul, 'Von Psychopathen, Technokraten des Terrors und ganz gewöhnlichen Deutschen. Die Täter der Shoah im Spiegel der Forschung', in Gerhard Paul (ed.), Die Täter der Shoah. Fanatische Nationalsozialisten oder ganz normale Deutsche? (2nd. ed., Göttingen, 2003), 13-90, here 16ff.

${ }^{9}$ Cit. Matthäus, 'Historiography’, 199.

${ }^{10}$ Eugen Kogon, The theory and practice of hell: the German concentration camps and the system behind them (London, 1950), 289. C.f. Paul, 'Psychopathen’, 19.

${ }^{11}$ Der Nürnberger Prozess. CD-ROM. Digitale Bibliothek. Vol. 20 (Berlin, 2002). For the English translation see <http://www.einsatzgruppenarchives.com/ohlendorf.html>.

${ }^{12}$ Joachim Perels, ‘Wahrnehmung und Verdrängung von NS-Verbrechen durch die Justiz', in Peter Gleichmann and Thomas Kühne (eds.), Massenhaftes Töten. Kriege und Genozide im 20. Jahrhundert (Essen, 2004), 361-371.

${ }^{13}$ Paul, 'Psychopathen', 18.

${ }^{14}$ See Anette Kretzer, ““His or her spezial job”. Die Repräsentation von NS-Verbrecherinnen im ersten Hamburger Ravensbrück-Prozess und im westdeutschen Täterschafts-Diskurs’, in KZ-Gedenkstätte Neuengamme (ed.), Entgrenzte Gewalt. Täterinnen und Täter im Nationalsozialismus (Bremen, 2002), 134-150.

${ }^{15}$ Moeller, Robert G., War Stories. The Search for a Usable Past in the Federal Republic of Germany (Berkeley, 2003).

${ }^{16}$ Ulrich Herbert, 'Extermination Policy: New Answers and Questions about the History of the “Holocaust” in German Historiography', in Ulrich Herbert (ed.), National Socialist Extermination Policies. Contemporary German Perspectives and Controversies (Oxford, 2000), 1-52, here 4.

${ }^{17}$ C.f. Ian Kershaw, Hitler: 1889-1936: Hubris (London, 1998), xxi-xxiii.

${ }^{18}$ See Eberhard Jäckel, Hitlers Weltanschauung: Entwurf einer Herrschaft (Tübingen, 1969); Rainer Zitelmann, Hitler. Selbstverständnis eines Revolutionärs (Hamburg, 1985); Kershaw, Hubris; Ian Kershaw, Hitler, 1936-1945: Nemesis (London, 2000). 
${ }^{19}$ Hans Buchheim, Wolfgang Broszat, Hans-Adolf Jacobsen, Helmut Krausnick (eds.), Anatomie des SS-Staates (Olten, 1965). See Herbert, ‘Extermination’, 5; Pohl, 'HolocaustForschung', 3.

${ }^{20}$ Peter Longerich, ‘Tendenzen und Perspektiven der Täterforschung’, Aus Politik und Zeitgeschichte, 14-15 (2. April 2007), 3-7, here 3f.

${ }^{21}$ E.g., see Karl Dietrich Bracher, Die deutsche Diktatur: Entstehung, Struktur, Folgen des Nationalsozialismus (Cologne, 1969); Karl Dietrich Bracher, Manfred Funke and Hans-Adolf Jacobsen (eds.), Nationalsozialistische Diktatur 1933-1945. Eine Bilanz (Bonn, 1983); Martin Broszat et al (eds.), Bayern in der NS-Zeit, 6 Vols. (Munich, 1977ff). C.f. Paul, 'Psychopathen', 28f.

${ }^{22}$ Uwe Dietrich Adam, Judenpolitik im Dritten Reich (Düsseldorf, 1972); Christian Streit, Keine Kameraden: Die Wehrmacht und die sowjetischen Kriegsgefangenen 1941-1945 (Stuttgart, 1978).

${ }^{23}$ C.f. Pohl, ‘Holocaust-Forschung', 4; Herbert, ‘Extermination’, 9.

${ }^{24}$ Ingo Haar and Michael Fahlbusch (eds.), German Scholars and Ethnic Cleansing 19191945 (Oxford, 2005), xi; Matthäus, 'Historiography’, 203.

${ }^{25}$ Herbert Jäger, Verbrechen unter totalitärer Herrschaft. Studien zur nationalsozialistischen Gewaltkriminalität (Frankfurt/Main, 1967). See Pohl, ‘Holocaust-Forschung’, 12f; Thomas Sandkühler, ‘Die Täter des Holocaust. Neuere Überlegungen und Kontroversen’, in KarlHeinrich Pohl, Wehrmacht und Vernichtungspolitik. Militär im nationalsozialistischen System (Göttingen, 1999), 39-65, here 42f; Kühne, ‘Vernichtungskrieg - Erster Teil’, $606 f$.

${ }^{26}$ C.f. Matthäus, 'Historiography’, 204.

${ }^{27}$ Raul Hilberg, The Politics of Memory. The Journey of a Holocaust Historian (Chicago, 1996), $141 \mathrm{ff}$.

${ }^{28}$ Lucy S. Dawidowicz, The War against the Jews 1933-1945 (New York, 1977); Nora Levin, The Holocaust. The Destruction of European Jewry 1933-1945 (New York, 1968). 
${ }^{29}$ Hannah Arendt, The Origins of Totalitarianism (London, 1986), xiv. This largely follows Matthäus, 'Historiography', 201f.

${ }^{30}$ Arendt, Totalitarianism, viii, 464f, 472.

${ }^{31}$ Raul Hilberg, The Destruction of the European Jews (London, 1961).

${ }^{32}$ Christopher R. Browning, ‘German Killers. Orders from Above, Initiative from Below, and the Scope of Local Autonomy - The Case of Brest-Litovsk', in Christopher R. Browning, (ed.), Nazi Policy, Jewish Workers, German Killers (Cambridge, 2000), 116-142, here 116.

${ }^{33}$ Paul, 'Psychopathen’, 27f; Kühne, 'Vernichtungskrieg - Erster Teil’, 594.

${ }^{34}$ Notable exceptions before 1961 are Léon Poliakov, Breviaire de la Haine. Le Troisiéme Reich et les Juifs (Paris, 1951); Gerald Reitlinger, The Final Solution: The Attempt to Exterminate the Jews of Europe, 1939-1945 (London, 1953).

${ }^{35}$ Hannah Arendt, Eichmann in Jerusalem: A Report on the Banality of Evil (rev. and enl. ed., New York, 1994), 295, 49, 148-150.

${ }^{36}$ For this and the following see Paul, 'Psychopathen', 21ff.

${ }^{37}$ Hilberg, Politics, 150; Paul, 'Psychopathen', $26 f$.

${ }^{38}$ Herbert, 'Extermination’, 8.

${ }^{39}$ Paul, 'Psychopathen’, 20ff. Also see Herbert, ‘Extermination’, 8.

${ }^{40}$ Zygmunt Bauman, Modernity and the Holocaust (Ithaca, N.Y., 1989), 12.

${ }^{41}$ James E. Young, The Texture of Memory: Holocaust Memorials and Memory (New Haven, 1993). For a world-wide overview, see David S. Wyman (ed.), The World Reacts to the Holocaust (London, 1996).

${ }^{42}<$ http://www.museum.tv/archives/etv/H/htmlH/holocaust/holocaust.htm>; Bill Niven, Facing the Nazi Past. United Germany and the Legacy of the Third Reich (London, 2002), 4.

${ }^{43}$ Detlef Garbe, 'Die Täter. Kommentierende Bemerkungen’, in Ulrich Herbert et al (eds.), Die nationalsozialistischen Konzentrationslager. Entwicklung und Struktur, vol. II (Göttingen, 1998), 822-838, here 823f.

${ }^{44}$ Matthäus, 'Historiography’, 205. 
${ }^{45}$ Helmut Krausnick and Hans-Heinrich Wilhelm, Die Truppe des Weltanschaungskrieges. Die Einsatzgruppen der Sicherheitspolizei und des SD 1938-1942 (Stuttgart, 1981); Ernst Klee, „Euthanasie“ im NS-Staat: Die „Vernichtung lebensunwerten Lebens“ (Frankfurt, 1983); Benno-Müller-Hill, Tödliche Wissenschaft: Die Aussonderung von Juden, Zigeunern und Geisteskranken, 1933-1945 (Reinbek, 1984); Gisela Bock, Zwangsterilisation im Nationalsozialismus (Opladen, 1986); Hans-Walter Schmuhl, Rassenhygiene, Nationalsozialismus, Euthanasie. Von der Verhütung zur Vernichtung „lebensunwerten Lebens“ 1890-1945 (Göttingen, 1987), Ulrich Herbert, Fremdarbeiter. Politik und Praxis des „Ausländer-Einsatzes“ in der Kriegswirtschaft des Dritten Reiches (Berlin, 1985); Burkhard Jellonek, Homosexuelle unter dem Hakenkreuz. Die Verfolgung der Homosexuellen im Dritten Reich (Paderborn, 1990). C.f. Kühne, 'Vernichtungskrieg - Erster Teil’, 596.

${ }^{46}$ E.g. see Ebbo Demant (ed.), Auschwitz - “Direkt von der Rampe weg ...” Kaduk, Erberg, Klehr: drei Täter geben zu Protokoll (Reinbek, 1979); Ernst Klee et al (eds.), „Schöne Zeiten“. Judenmord aus der Sicht der Täter und Gaffer (Frankfurt/Main, 1988); Ortwin Buchbender and Reinhold Sterz (eds.), Das andere Gesicht des Krieges. Deutsche Feldpostbriefe 1939-1945 (2nd. ed., Munich, 1983). See Paul, ‘Psychopathen’, 33ff; Kühne, 'Vernichtungskrieg - Erster Teil’, 637.

${ }^{47}$ Michael Zimmermann, Verfolgt, vertrieben, vernichtet. Die nationalsozialistische Vernichtungspolitik gegen Sinti und Roma (Essen, 1989). Cit. Herbert, 'Extermination’, 15.

${ }^{48}$ Henry V. Dicks, Licensed Mass Murder. A Social-psychological study of some SS killers (Edinburgh, 1972); Gitta Sereny, Am Abgrund. Eine Gewissensforschung. Gespräche mit Franz Stangl, Kommandant von Treblinka, und anderen (Frankfurt/Main, 1979); Stein Ugelvik Larsen et al (eds.), Who were the Fascists. Social Roots of European Fascism (Bergen, 1980); Tom Sevev, Soldiers of Evil. The Commandants of the Nazi Concentration Camps (New York, 1988); Charles W. Sydnor, Soldiers of Destruction: The SS-Death's Head Division, 1933-1945 (Princeton, 1977). See Paul, 'Psychopathen’, 34ff. 
${ }^{49}$ Omer Bartov, The Eastern Front, 1941-1945. German Troops and the Barbarisation of Warfare (Houndmills, 1985); 144, 152f; Omer Bartov, Hitler’s Army. Soldiers, Nazis and War in the Third Reich (New York, 1991), 182.

${ }^{50}$ Niven, Facing, esp. 1-4.

${ }^{51}$ Christopher Browning, Ordinary Men. Reserve Police Battalion 101 and the Final solution in Poland (orig. New York, 1992; this ed. London, 2001).

${ }^{52}$ Stanley Milgram, Obedience to Authority: An Experimental View (New York, 1974); Craig Haney, Curtis Banks and Philip Zimbardo, 'Interpersonal Dynamics in a Simulated Prison', International Journal of Criminology and Penology, 1 (1973), 69-97.

${ }^{53}$ Bogdan Musial, Deutsche Zivilverwaltung und Judenverfolgung im Generalgouvernement. Eine Fallstudie zum Distrikt Lublin 1939-1944 (Wiesbaden, 1999); Christian Gerlach, Kalkulierte Morde: die deutsche Wirtschafts- und Vernichtungspolitik in Weißrußland 1941 bis 1944 (Hamburg, 1999); Dieter Pohl, Nationalsozialistische Judenverfolgung in Ostgalizien 1941-1944 (Munich, 1996).

${ }^{54}$ Browning, Ordinary Men, 186-188. See Primo Levi, ‘The Gray Zone’, in Primo Levi, The Drowned and the Saved (New York, 1989), 36-69. C.f. Paul, 'Psychopathen', 38.

${ }^{55}$ Daniel Jonah Goldhagen, Hitler's Willing Executioners. Ordinary Germans and the Holocaust (New York, 1997), 407; Hamburger Institut für Sozialforschung (ed.), Vernichtungskrieg. Verbrechen der Wehrmacht 1941 bis 1944. Ausstellungskatalog (Hamburg, 1996).

${ }^{56}$ Matthäus, 'Historiography’, 209; Kühne, ‘Vernichtungskrieg - Erster Teil’, 587, 590, 650.

${ }^{57}$ Paul, 'Psychopathen', 41.

${ }^{58}$ For this and the above see Kühne, 'Vernichtungskrieg - Erster Teil', 609. Meanwhile, see, for example, Frank Bajohr, “Unser Hotel ist judenfrei “: Bäder-Antisemitismus im 19. und 20. Jahrhundert (Frankfurt/Main, 2003); Cornelia Hecht, Deutsche Juden und Antisemitismus in der Weimarer Republik (Bonn, 2003); Saul Friedländer, Nazi Germany and the Jews. The Years of Persecution 1933-39 (London, 1997); Saul Friedländer, Das Dritte Reich und die 
Juden. Die Jahre der Vernichtung, 1939-1945 (Munich, 2006); Peter Longerich, “Davon haben wir nichts gewusst!” Die Deutschen und die Judenverfolgung 1933-1945

(Frankfurt/Main, 2006).

${ }^{59}$ Götz Aly and Susanne Heim, Vordenker der Vernichtung. Auschwitz und die deutschen Pläne für eine neue europäische Ordnung (Hamburg, 1991).

${ }^{60}$ Götz Aly, „Endlösung“. Völkerverschiebung und der Mord an den europäischen Juden (Frankfurt/Main, 1995).

${ }^{61}$ Herbert, ‘Extermination’, 14.

${ }^{62}$ Paul, 'Psychopathen’, 43; Pohl, 'Holocaust -Forschung’, 8; Hans Mommsen,

'Forschungskontroversen zum Nationalsozialismus', Aus Politik und Zeitgeschichte, 14-15 (2. April 2007), 14-21, here 16f.

${ }^{63}$ Kühne, ‘Vernichtungskrieg - Erster Teil’, 615. Michael Wildt, Generation des Unbedingten. Das Führungskorps des Reichssicherheitshauptamtes (Hamburg, 2002). For this and the following also see Paul, 'Psychopathen', 43ff; George C. Browder, 'Perpetrator Character and Motivation: An Emerging Consensus?', Holocaust and Genocide Studies, 17 (3) (Winter 2003), 480-497, esp. 480ff.

${ }^{64}$ Browder, 'Perpetrator', 495. E.g. see Martin Cüppers, Wegbereiter der Shoa. Die WaffenSS, der Kommandostab Reichsführer-SS und die Judenvernichtung 1939-1945 (Darmstadt 2005); Mallmann/Paul, Gestapo; Michael Wildt (ed.), Nachrichtendienst, politische Elite und Mordeinheit. Der Sicherheitsdienst des Reichsführers SS (Hamburg, 2003); Karin Orth, Die Konzentrationslager-SS: Sozialstrukturelle Analysen und biographische Studien (Göttingen, 2000); Ulrich Herbert, Best. Biographische Studien über Radikalismus, Weltanschauung und Vernunft, 1903-1989 (Bonn, 1996); Götz Aly, et al (eds.), Cleansing the Fatherland. Nazi Medicine and Racial Hygiene (Baltimore, London, 1994).

${ }^{65}$ Gerald D. Feldman and Wolfgang Seibel (eds.), Networks of Nazi Persecution. Bureaucracy, Business and the Organization of the Holocaust (Oxford, 2005); Michael Thad 
Allen, The Business of Genocide: The SS, Slave Labor, and the Concentration Camps (London, 2002).

${ }^{66}$ Browder, 'Perpetrator', 481. Also see Michael Mann, 'Were the Perpetrators of Genocide “Ordinary Men” or “Real Nazis”? Results from Fifteen Hundred Biographies’, Holocaust and Genocide Studies, 14 (3) (2000), 331-366.

${ }^{67}$ Andrej Angrick, Besatzungspolitik und Massenmord. Die Einsatzgruppe D in der südlichen Sowjetunion 1941-1943 (Hamburg, 2003), esp. 386-450.

${ }^{68}$ Klaus-Michael Mallmann, 'Der Einstieg in den Genozid. Das Lübecker Polizeibataillon 307 und das Massaker in Brest-Litowsk Anfang Juli 1941’, Archiv für Polizeigeschichte, 10 (3) (1999), 82-88; cit. Paul, ‘Psychopathen’, 52f.

${ }^{69}$ See Rolf-Dieter Müller and Gerd R. Ueberschär (eds.), Hitler’s War in the East. A Critical Assessment (Oxford, 2002); Thomas Kühne, Kameradschaft. Die Soldaten des nationalsozialistischen Krieges und das 20. Jahrhundert (Göttingen, 2006), 272.

${ }^{70}$ Claudia Koonz, Mothers in the Fatherland. Women, the Family and Nazi Politics (New York, 1987); Gisela Bock, ‘Die Frauen und der Nationalsozialismus: Bemerkungen zu einem Buch von Claudia Koonz’, Geschichte und Gesellschaft, 15 (4) (1989), 563-579. See Kirsten Heinsohn et al, ‘Einleitung’, in Kirsten Heinsohn et al (eds.), Zwischen Karriere und Verfolgung. Handlungsräume von Frauen im nationalsozialistischen Deutschland, (Frankfurt/Main, 1997), 7-23.

${ }^{71}$ For an overview see Susannah Heschel, 'Does Atrocity Have a Gender? Feminist Interpretations of Women in the SS', in J. M. Diefendorf (ed.), Lessons and Legacies VI. New Currents in Holocaust Research (Evanston, Illinois, 2004), 300-324.

${ }^{72}$ E.g., see Lehnert, Die Beteiligung von Fürsorgerinnen an der Bildung und Umsetzung der Kategorie "minderwertig" im Nationalsozialismus. Öffentliche Fürsorgerinnen in Berlin und Hamburg im Spannungsfeld von Auslese und "Ausmerze" (Frankfurt/Main, 2003); Claudia Taake, Angeklagt: SS-Frauen vor Gericht (Oldenburg, 1998). 
${ }^{73}$ Gudrun Schwarz, Eine Frau an seiner Seite. Ehefrauen in der „SS-Sippengemeinschaft“

(Hamburg, 1997); Gudrun Schwarz, ‘Frauen in Konzentrationslagern - Täterinnen und

Zuschauerinnen’, in Herbert, Konzentrationslager, 800-821.

${ }^{74}$ Dean, 'Where?’, 798.

${ }^{75}$ For this and the following see Martin Dean, 'Schutzmannschaften in Ukraine and Belarus:

Profiles of Local Police Collaboration', in Dagmar Herzog (eds.), Lessons and Legacies. The Holocaust in International Perspective (vol. VII; Evanston/Illinois, 2006), 219-232, esp. 226229. Also see Ruth B. Birn, Die Sicherheitspolizei in Estland 1941-1944. Eine Studie zur Kollaboration im Osten (Paderborn, 2006); Bernd Chiari, Alltag hinter der Front. Besatzung, Kollaboration und Widerstand in Weißrußland 1941-1944 (Düsseldorf, 1998).

${ }^{76}$ For the following see Robert Gelatelly and Ben Kiernan, 'The Study of Mass Murder and Genocide', in Robert Gelatelly and Ben Kiernan (eds.), The Specter of Genocide: Mass Murder in Historical Perspective (Cambridge, 2003), 3-26.

${ }^{77}$ James Waller, Becoming Evil: How Ordinary People Commit Genocide and Mass Killing (Oxford, 2002).

${ }^{78}$ Harald Welzer, Täter. Wie aus ganz normalen Menschen Massenmörder werden (Frankfurt, 2005).

${ }^{79}$ Peter Longerich, Politik der Vernichtung. Eine Gesamtdarstellung der nationalsozialistischen Judenverfolgung (Munich, 1998); Christopher R. Browning, The Origins of the Final Solution: The Evolution of Nazi Jewish Policy, September 1939-March 1942. With contributions by Jürgen Matthäus (Lincoln, 2004).

${ }^{80}$ For this and the following see Klaus-Michael Mallmann and Gerhard Paul, 'Sozialisation, Milieu und Gewalt. Fortschritte und Probleme der neueren Täterforschung', in Klaus-Michael Mallmann and Gerhard Paul (eds.), Karrieren der Gewalt. Nationalsozialistische Täterbiographien (Darmstadt, 2005), 1-32, esp. 1f, 5, 9-16. For a recent discussion also see Mark Roseman, 'Beyond Conviction? Perpetrators, Ideas and Action in the Holocaust in 
Historiographical Perspective', in Frank Biess et al (eds.), Conflict, Catastrophe and Continuity: Essays on Modern Germany History (Oxford, 2007), 83-103.

${ }^{81}$ Dieter Pohl, Verfolgung und Massenmord in der NS-Zeit 1933-1945 (Darmstadt, 2003), $154 f$.

${ }^{82}$ Leonard S. Newman and Ralph Erber (eds.), Understanding Genocide: The Social Psychology of the Holocaust (New York, 2002), 50-53, cit. Browder, 'Perpetrator', 493f.

${ }^{83}$ For research desiderata about Nazi occupied territories of the Soviet Union, see Dieter Pohl, 'Die einheimische Forschung und der Mord an den Juden in den besetzten sowjetischen Gebieten’, in Wolf Kaiser (ed.), Täter im Vernichtungskrieg. Der Überfall auf die Sowjetunion und der Völkermord an den Juden (Berlin, 2002), 204-216.

${ }^{84}$ Christopher R. Browning, 'Postscript’, in Browning, Nazi Policy, 170-175, here 175.

${ }^{85}$ Browder, 'Perpetrator', 495.

${ }^{86}$ Claudia Koonz, The Nazi Conscience (Cambridge, MA, 2003).

${ }^{87}$ Pohl, 'Holocaust-Forschung', 11.

${ }^{88}$ Browder, 'Perpetrator’, 481.

${ }^{89}$ For a recent exception, see Christoph Dieckmann, Deutsche Besatzungs- und Vernichtungspolitik in Litauen 1941 bis 1944 (Hamburg, 2004).

${ }^{90}$ Matthäus, ‘Historiography', 209.

${ }^{91}$ Harvey Asher, ‘Ganz normale Täter. Variablen sozialpsychologischer Analysen’, Zeitschrift für Genozidforschung, 3 (1/2) (2001), 81-115.

${ }^{92}$ Heschel, ‘Gender?’, 314. More recently, see Elizabeth Harvey, Women and the Nazi East. Agents and Witnesses of Germanization (New Haven, 2003).

${ }^{93}$ Anna E. Sosmus, Widerstand und Verfolgung am Beispiel Passaus 1933-1939 (Passau, 1983); also see Michael Verhoeven’s film ‘Das schreckliche Mädchen’ (The Nasty Girl) from 1990. Harald Welzer (ed.), Der Krieg der Erinnerung. Holocaust, Kollaboration und Widerstand im europäischen Gedächtnis (Frankfurt/Main, 2007). 
${ }^{94}$ Antony Polonsky and Joanna B. Michlic (eds.), The Neighbors Respond: The Controversy over the Jedwabne Massacre in Poland (Oxford, 2004).

${ }^{95}$ Longerich, ‘Tendenzen’, 4; Saul Friedländer, ‘Eine integrierte Geschichte des Holocaust’, Aus Politik und Zeitgeschichte, 14-15 (2. April 2007), 7-14, here 9ff; Ulrich Herbert, 'The Holocaust in German Historiography: Some Introductory Remarks’, in Moshe Zimmermann (ed.), On Germans and Jews under the Nazi Regime. Essays by Three Generations of Historians (Jerusalem, 2006), 67-84, here 82f. 